University of Nebraska - Lincoln

DigitalCommons@University of Nebraska - Lincoln

Nebraska Game and Parks Commission -- Staff

Research Publications

Nebraska Game and Parks Commission

January 1968

\title{
Some Ecological Observations on the Fathead Minnow, Pimephales promelas, in the Alkaline Waters of Nebraska
}

\author{
D. B. McCarraher \\ Nebraska Game, Forestation and Parks Commission \\ Robert Thomas \\ Nebraska Game, Forestation and Parks Commission
}

Follow this and additional works at: https://digitalcommons.unl.edu/nebgamestaff

Part of the Environmental Sciences Commons

\begin{abstract}
McCarraher, D. B. and Thomas, Robert, "Some Ecological Observations on the Fathead Minnow, Pimephales promelas, in the Alkaline Waters of Nebraska" (1968). Nebraska Game and Parks Commission -- Staff Research Publications. 8.

https://digitalcommons.unl.edu/nebgamestaff/8
\end{abstract}

This Article is brought to you for free and open access by the Nebraska Game and Parks Commission at DigitalCommons@University of Nebraska - Lincoln. It has been accepted for inclusion in Nebraska Game and Parks Commission -- Staff Research Publications by an authorized administrator of DigitalCommons@University of Nebraska - Lincoln. 
A reprint from the

TRANSACTIONS of the AMERICAN FISHERIES SOCIETY

\author{
Vo Tume 97 Number 1 \\ January 1968
}

Published Quarterly

\section{Some Ecological Observations on the Fathead Minnow, Pimephales promelas, in the Alkaline Waters of Nebraska INTRODUCTION}

Populations of the fathead minnow, Pimephales promelas, were apparently common throughout the sandhills region of Nebraska, prior to the appearance of the first pioneers, for Aughey (1880) listed the species as part of the native fauna. Current data relating to the distribution (Figure 1) and gross ecology of the species throughout the sandhills, was first collected in 1954 by the authors, with continuous observances recorded since that year. The fathead minnow is a common species throughout the northern great plains and appears to reach its greatest abundance in the shallow, alkaline lakes of Nebraska. Our investigations over the past ten years indicates that the species is found in about 240 sandhill lakes with population densities variable according to alkalinity content of the lake. Only one monographic report by Izaak (1961) reflects on the life history of the minnow in
North America. Adequate information is not available indicating water quality parameters. It is the intent of this paper to describe some of the ecological characteristics that reflect the life history of the fathead minnow in the alkaline sandhill lakes of Nebraska.

\section{ABUNDANCE AND DISTRIBUTION}

Field observations clearly demonstrate that the abundance of the fathead minnow closely follows seasonal changes in individual lake water quality (Tables 1 and 2 ). Populations in Smithys Lake flourish during the spring months when carbonate alkalinity remains below $800 \mathrm{ppm}$ and the total alkalinity does not exceed $1,800 \mathrm{ppm}$. Chemical conditions in excess of these values appear to greatly impair the reproduction and abundance of the minnow.

In East Twin Lake, the annual water quality varies drastically from year to year causing a complete disappearance of the minnow during years of high alkalinity values. The senior author first recorded the fathead minnow population and water chemistry in East Twin Lake 


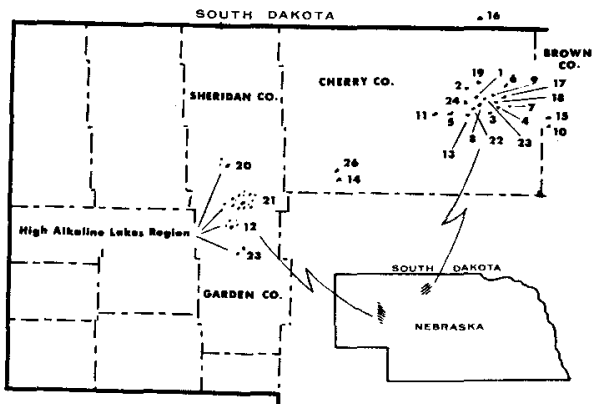

Ficure 1. Fathead Minnow Study Lakes (Numbers refer to Tables 1 and 2 ).

during 1959 when the total alkalinity values were between 875-940 ppm. By 1961 when the water level receded and the resultant total alkalinity readings reached $3,575 \mathrm{ppm}$ the fathead minnow population in East Twin Lake disappeared. Increased water level and decreased alkalinity below $2,000 \mathrm{ppm}$ brought about the re-establishment of the fathead minnows by late 1962 . It is believed that repopulation was established by migrating shorebirds and waterfowl transporting viable fish eggs adhering to external surfaces of the birds.

Abundance and distribution are probably regulated, to a lesser extent, by interspecific competition from other fish species. Intraspecifc activity versus populated density was not evaluated during this study.

In Horseshoe Lake, Minnesota, the resident fish population of fivespine stickleback, Culaca inconstans (Kirtland); mud minnow, Umbra limi (Kirtland); and the black bullhead, Ictalurus melas (Raf.), did not appear to interfere with the normal activities of the fathead minnow (Izaak, 1961).

In Rodgers, Dads, Ell, Skull, and Mule Lakes of the Nebraska sandhills region black bullhead and green sunfish, Lepomis cyanellus (Rafinesque) are abundant and feed to some extent on the minnows.

During most winters a depletion of dissolved oxygen may occur in several of the shallower lakes, notably Rodgers, White, East Twin, and McKeel Pond \#1. Dissolved oxygen content below $0.8 \mathrm{ppm}$ greatly reduced the minnow population in these lakes. The mortality appeared to be greatest among the age 0 group.
Rawson and Moore (1944) noted fathead minnow survival in the Saskatchewan sulfate lakes having nearly $15,000 \mathrm{ppm}$ total solids. These lakes differ chemically from the alkaline water conditions prevailng in Nebraska sites (Tables 1 and 2).

White Lake, South Dakota, located a few miles north of the Nebraska border has maintained a high population of fathead minnows for many years. The lake contains a higher proportion of sulfate and chloride ions than the Nebraska sandhill lakes and should be classified as a sodium-sulfate type (Table 1). Its total alkalinity ranges from $830 \mathrm{ppm}$ (1960) to 2,600 ppm (1965) and fluctuates widely each year. The maximum total solids recorded was 3,862 ppm in March, 1965.

\section{GROWTH}

The male minnows often grow to large size in the higher alkaline lakes. Several specimens were collected from Smithys Lake during late summer having a total length of 90-101 mm. These minnow lengths exceed that reported by Carlander (1950). Izaak (1961) collected fish up to $69 \mathrm{~mm}$ total length during the late fall months while Markus (1934) reared males up to the maximum size of $78 \mathrm{~mm}$ in small rearing ponds. All specimens were age 1 or less.

The growth rate of the sandhill populations appears to be influenced by water quality, food supply, and density of the population. Those alkaline lakes, where total alkalinity annually ranges between $800-1,800 \mathrm{ppm}$, have provided the largest specimens. These same alkaline lakes are characterized by high densities of zooplankton and phytoplankton populations. Winter dissolved oxygen depletion periodically removes a portion of the fathead minnow population thus alleviating crowding and consequently greatly reduces intraspecific competition.

\section{REPRODUCTION}

Fathead minnows have successfully spawned in alkaline lakes where the total alkalinity during the spring and early summer does not exceed 2,000 ppm. Spawning success appears to decline sharply above this value. Carbonate alkalinity was found to present toxic environmental conditions for natural recruitment above $850 \mathrm{ppm}$ concentrations (Table 2). 
TABLE 1.-Physical and average chemical conditions of lakes in which fathead minnows have survived for six or more months

\begin{tabular}{|c|c|c|c|c|c|c|c|c|c|c|c|c|c|c|}
\hline Lake & $\underset{\text { ber }^{1}}{\text { Num- }}$ & $\begin{array}{l}\text { Sur- } \\
\text { face } \\
\text { acres }\end{array}$ & $\begin{array}{l}\text { Average } \\
\text { depth. } \\
\text { (ft.) }\end{array}$ & $\mathrm{CO}_{3}$ & $\mathrm{HCO}_{\mathrm{s}}$ & $\mathbf{p H}$ & $\mathbf{N a}$ & $\mathbf{K}$ & $\mathrm{Ca}$ & $\mathrm{SO}_{4}$ & $\mathbf{M g}$ & Cl & $\begin{array}{c}\text { Total } \\
\text { hard- } \\
\text { ness }\end{array}$ & $\begin{array}{l}\text { Total } \\
\text { solids }\end{array}$ \\
\hline $\begin{array}{l}\text { Rodgers } \\
\text { Hudson } \\
\text { McKeel } \\
\text { McKeel Pond \#1 } \\
\text { Mule } \\
\text { East Twin } \\
\text { Ell } \\
\text { By-Way } \\
\text { Smithys \#4 } \\
\text { Skull } \\
\text { Stout } \\
\text { Bean } \\
\text { Dads } \\
\text { South Twin } \\
\text { Skull \#1 } \\
\text { White, S.D. }\end{array}$ & $\begin{array}{r}1 \\
2 \\
3 \\
4 \\
\mathbf{5} \\
6 \\
7 \\
8 \\
9 \\
10 \\
11 \\
12 \\
13 \\
14 \\
15 \\
16\end{array}$ & $\begin{array}{r}22 \\
130 \\
48 \\
0.6 \\
348 \\
67 \\
120 \\
36 \\
1 \\
60 \\
12 \\
259 \\
1025 \\
45 \\
72 \\
230\end{array}$ & $\begin{array}{l}3.0 \\
4.5 \\
3.2 \\
3.5 \\
4.8 \\
3.2 \\
3.8 \\
3.5 \\
2.8 \\
4.2 \\
4.5 \\
4.8 \\
5.6 \\
4.6 \\
3.0 \\
3.2\end{array}$ & $\begin{array}{r}332 \\
260 \\
408 \\
208 \\
78 \\
\mathbf{5 6 7} \\
148 \\
674 \\
420 \\
123 \\
202 \\
374 \\
88 \\
442 \\
124 \\
466\end{array}$ & $\begin{array}{r}632 \\
464 \\
442 \\
1492 \\
385 \\
1378 \\
420 \\
1305 \\
986 \\
582 \\
94 \\
969 \\
248 \\
918 \\
876 \\
903\end{array}$ & $\begin{array}{l}9.2 \\
9.1 \\
9.2 \\
9.4 \\
8.8 \\
9.4 \\
9.2 \\
9.5 \\
9.3 \\
9.0 \\
9.2 \\
9.1 \\
9.3 \\
9.2 \\
8.8 \\
9.1\end{array}$ & $\begin{array}{l}300 \\
350 \\
300 \\
450 \\
655 \\
267 \\
475 \\
600 \\
80 \\
130 \\
500 \\
400 \\
435\end{array}$ & $\begin{array}{l}215 \\
300 \\
150 \\
250 \\
500 \\
189 \\
330 \\
300 \\
92 \\
95 \\
310 \\
150 \\
187\end{array}$ & $\begin{array}{l}16 \\
43 \\
43 \\
40 \\
82 \\
22 \\
26 \\
46 \\
46 \\
37 \\
56 \\
14 \\
34 \\
48 \\
33\end{array}$ & $\begin{array}{c}14 \\
60 \\
20 \\
60 \\
12 \\
43 \\
7 \\
6 \\
14 \\
80 \\
38 \\
6 \\
25 \\
20 \\
620^{*}\end{array}$ & $\begin{array}{r}152 \\
22 \\
5 \\
9 \\
20 \\
11 \\
23 \\
16 \\
11 \\
- \\
4 \\
11 \\
2 \\
0.0\end{array}$ & $\begin{array}{r}34 \\
30 \\
80 \\
100 \\
72 \\
143 \\
29 \\
120 \\
16 \\
37 \\
98 \\
21 \\
118 \\
120 \\
122\end{array}$ & $\begin{array}{r}768 \\
200 \\
128 \\
136 \\
102 \\
100 \\
160 \\
62 \\
160 \\
119 \\
52 \\
128 \\
128 \\
29\end{array}$ & $\begin{array}{r}1,400 \\
1,546 \\
1,012 \\
2,118 \\
540 \\
2,323 \\
1,000 \\
2,197 \\
1,878 \\
817 \\
600 \\
1,343 \\
594 \\
2,292 \\
1,334 \\
1,880\end{array}$ \\
\hline \multicolumn{4}{|c|}{ Average Chemical Conditions } & 307 & 754 & 9.1 & 380 & 236 & 36 & 29 & 23 & 76 & 162 & 1,429 \\
\hline
\end{tabular}

* Not included in total average.

I For location of lakes see Figure 1.

- Not recorded.

In the Smithys Lake drainage system, where occasionally the alkaline content of the lake restricts reproduction, fathead minnows may ascend a drainage marsh where the water is considerably less alkaline. Where the total alkalinity is about $300 \mathrm{ppm}$ the natural recruitment and their downstream movement from the marsh replenishes the minnow population of Smithys Lake.

Spawning commences about the third week of April when surface water temperatures reach 58-65 F. Fathead minnow eggs have been collected from fence posts, barb wire, and the stems of hardstem bulrush, Scirpus americanus. Although sago pondweed, Potemogeton pectinatus, and Chara sp., are the common submergent plants in the alkaline lakes few eggs have been' collected from these plants. All egg deposits on fences and bulrush stems were encountered at depths of \pm 3 feet. These spawning depths closely parallel the findings by Izaak (1961).

In those sandhill lakes where fathead minnows are especially abundant the populations have coelomic cavity infestations of the cestoda, Ligula intestinalis. This parasite appears to greatly restrict the reproductive potential of the host with female hosts containing about $42 \%$ fewer eggs than noninfected hosts. This percentage is based on the examination of ovaries from 182 infected fish from White and Rodgers lakes and 62 noninfected fish from other lakes.

Of the 290 adult minnows of both sexes

TABLE 2--Average physical and chemical conditions of sandhill lakes where fathead minnows survive six months or less

\begin{tabular}{|c|c|c|c|c|c|c|c|c|c|c|c|c|c|c|c|}
\hline Lake & $\operatorname{Num}_{\text {ber }^{1}}$ & $\begin{array}{c}\text { Sur- } \\
\text { face } \\
\text { acres }\end{array}$ & $\begin{array}{c}\text { Average } \\
\text { depth } \\
\text { (ft.) }\end{array}$ & $\mathrm{CO}_{3}$ & $\mathrm{HCO}_{3}$ & pH & $\mathbf{N a}$ & $\mathbf{K}$ & $\mathrm{Ca}$ & $\mathrm{SO}_{4}$ & $\mathbf{M g}$ & Cl & $\begin{array}{c}\text { Total } \\
\text { hard- } \\
\text { ness }\end{array}$ & $\begin{array}{l}\text { Total } \\
\text { solids }\end{array}$ & $\begin{array}{l}\text { Survival } \\
\text { period } \\
\text { (days) }\end{array}$ \\
\hline $\begin{array}{l}\text { Smithys \#1 } \\
\text { Smithys \#2 } \\
\text { Little Alkali } \\
\text { Diamond } \\
\text { Lakeside } \\
\text { McKeel \#2 } \\
\text { Goose } \\
\text { School } \\
\text { Smithys } \\
\text { North Twain }\end{array}$ & $\begin{array}{l}17 \\
18 \\
19 \\
20 \\
21 \\
22 \\
23 \\
24 \\
25 \\
26\end{array}$ & $\begin{array}{r}1.0 \\
1.2 \\
38 \\
318 \\
85 \\
0.5 \\
364 \\
84 \\
40 \\
74\end{array}$ & $\begin{array}{l}1.5 \\
1.8 \\
4.0 \\
4.2 \\
3.2 \\
2.5 \\
4.0 \\
4.2 \\
4.0 \\
4.2\end{array}$ & $\begin{array}{r}655 \\
760 \\
987 \\
842 \\
5060 \\
782 \\
610 \\
680 \\
720 \\
316\end{array}$ & $\begin{array}{r}2215 \\
1778 \\
1951 \\
1610 \\
15700 \\
904 \\
2060 \\
731 \\
2580 \\
1884\end{array}$ & $\begin{array}{r}9.7 \\
9.8 \\
9.8 \\
9.5 \\
10.1 \\
9.2 \\
9.7 \\
9.4 \\
9.6 \\
9.6\end{array}$ & $\begin{array}{r}2100 \\
2000 \\
728 \\
722 \\
7000 \\
1100 \\
780 \\
1000 \\
1200 \\
750\end{array}$ & $\begin{array}{r}850 \\
900 \\
775 \\
822 \\
10872 \\
1200 \\
550 \\
550 \\
800 \\
\mathbf{2 5 0}\end{array}$ & $\begin{array}{r}0.0 \\
0.0 \\
16 \\
17 \\
0.0 \\
59 \\
60 \\
21 \\
51 \\
35\end{array}$ & $\begin{array}{r}180 \\
162 \\
101 \\
251 \\
1540 \\
40 \\
140 \\
60 \\
38 \\
40\end{array}$ & $\begin{array}{r}18 \\
10 \\
206 \\
30 \\
1 \\
1 \\
12 \\
1 \\
8 \\
6\end{array}$ & $\begin{array}{r}68 \\
56 \\
155 \\
194 \\
1600 \\
140 \\
300 \\
100 \\
180 \\
100\end{array}$ & $\begin{array}{r}14 \\
8 \\
35 \\
209 \\
159 \\
140 \\
56 \\
160 \\
112\end{array}$ & $\begin{array}{r}3590 \\
5390 \\
3450 \\
3440 \\
27708 \\
4358 \\
3710 \\
3248 \\
4650 \\
2388\end{array}$ & $\begin{array}{c}30-38 \\
36-45 \\
10-13 \\
8-12 \\
4-12 \text { hrs. } \\
80-84 \\
70-94 \\
60-80 \\
60-135 \\
\text { Not known }\end{array}$ \\
\hline \multicolumn{4}{|c|}{ Average Chemical Conditions } & 1141 & 3141 & 9.6 & 1738 & 1756 & 26 & 255 & 29 & 239 & 105 & 6193 & \\
\hline
\end{tabular}

\footnotetext{
1 For location of lakes see Figure 1 .

2 Age $O \&$ I fathead minnows were placed in live cages and set in various depths in the lakes. Survival period reflects approximated number of days when first mortality appeared and total mortality of test fish in individual cages. 
examined from Rodgers Lake, $88 \%$ contained one or more Ligula intestinalis. The incidence of infestation (79\%) was also high in the White Lake populations. The number of Ligula intestinalis per infected minnow ranged from 1 to 22 with no direct relationship between the total length of the host and the total number of parasitic cestoda present.

In contrast to the heavy incidence of Ligula intestinalis found in several sandhill lakes, Izaak (1961) found this parasite in only $0.03 \%$ of the coelomic cavities of specimens from Horseshoe Lake.

\section{ACKNOWLEDGMENT}

Dr. Charles B. Curtin, The Creighton University, Omaha, furnished the minnow parasite information.

\section{LITERATURE CITED}

Augher, Sammuer. 1880. Sketches of the physical geography and geology of Nebraska. Daily Republican Book and Job Office. Omaha. pp. 129 130.

Carlander, K. D. 1950 . Handbook of Freshwater Fishery Biology. Wm. C. Brown Co., 281 p.

Izank, Daniel. 1961. The ecological life history of the fathead minnow, Pimephales promelas (Rafinesque). Ph.D. thesis. Univ. Minnesota.

Markus, Henry C. 1934. Life history of the blackhead minnow, Pimephales promelas. Copeia 1934 (3) : 116-122.

Rawson, D. S., and J. E. Moore. 1944. The saline lakes of Saskatchewan. Can. Res. 22: 141-201 p. Trautman, Milton B. 1957. The fishes of Ohio. Ohio State Univ. Press. 683 p.

D. B. McCarraher

Nebraska Game, Forestation and Parks Commission

Hastings College

Hastings, Nebraska

Robert Thomas

Nebraska Game, Forestation and Parks Commission Lincoln, Nebraska 